\title{
The seabed geomorphology and geological structure of the Firth of Lorn, western Scotland, UK, as revealed by multibeam echo-sounder survey
}

\author{
John A. Howe ${ }^{1}$, Roger Anderton ${ }^{2}$, Riccardo Arosio ${ }^{1}$, Dayton Dove ${ }^{3}$, \\ Tom Bradwell ${ }^{3}$, Philip Crump ${ }^{1}$, Rhys Cooper ${ }^{3}$ and Andre Cocuccio ${ }^{4}$
}

\author{
${ }^{1}$ Scottish Association for Marine Science, Scottish Marine Institute, Oban PA37 1QA, UK. \\ ${ }^{2}$ Kilmichael House, Kilmichael Glassary, Lochgilphead PA31 8QA, UK. \\ ${ }^{3}$ British Geological Survey, Murchison House, West Mains Rd, Edinburgh EH9 3LA, UK. \\ ${ }^{4}$ Maritime and Coastguard Agency, Spring Place, 105 Commercial Road, Southampton SO15 1EG, UK.
}

\begin{abstract}
This paper presents recently collected swath bathymetry from the Firth of Lorn. $553 \mathrm{~km}^{2}$ of data were collected during 2012-2013 as part of the INIS Hydro (Ireland, Northern Ireland and Scotland Hydrographic Survey) programme.

The area proves to consist of bedrock-dominated seabed, divided into narrow, stratigraphicallyconstrained and glacially-over-deepened basins. The bedrock is composed of late Proterozoic Dalradian metasediments overlain unconformably by Old Red Sandstone (ORS) sediments and lavas of ?Silurian-age. The central region of the Firth of Lorn is dominated by a vertical cliff, up to $150 \mathrm{~m}$ high and extending for approximately $24 \mathrm{~km}$. This feature, here termed the Insh Fault, may have originated as a Dalradian extensional fault, been reactivated as an ORS feature and now forms a fault-line scarp with resistant ORS rocks on the downthrown side, flanking the more deeply eroded metasediments exposed in the basin. Tertiary intrusives are common, in particular, swarms of Paleocene dolerite dykes exposed on the sediment-free bedrock surfaces, and can be traced for many kilometres.

Evidence for past glaciation is widespread, manifest in the extensive erosion of the bedrock platforms and the abundance of well-preserved moraines and over-deepened basins. The survey region includes the Corryvreckan Whirlpool and Great Race, beneath the tidal flows of which occur submarine dunes.
\end{abstract}

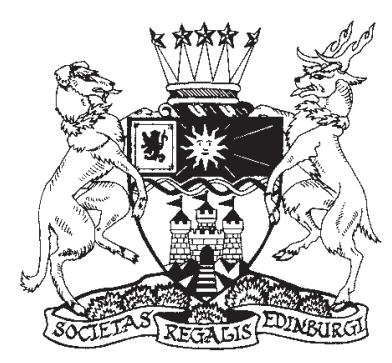

KEY WORDS: Dalradian metasediments, faulting, Old Red Sandstone, pock marks, submarine dunes

The submarine geomorphology of the UK Continental Shelf (UKCS) reflects its geological history; its underlying solid geology and Quaternary sediment cover. Both can become overprinted with a record of glaciation and subsequent, more recent, hydrodynamic processes such as tidal movement and sea level change. Previous studies have demonstrated how an understanding of the geomorphology of the Continental Shelf is an essential tool in understanding physical processes such as tidal flows (Shaw et al. 2012), sediment movement (Cazanave 2012), benthic habitats (Brown \& Blondel 2009) and glacial history (Bradwell et al. 2008; Howe et al. 2012; Ó Cofaigh et al. 2012).

The Firth of Lorn is located on the west coast of Scotland and includes the SW extension of the Great Glen Fault, a major tectonic lineament traversing Scotland from Inverness in the NE to beyond Oban in the SW. The fault line occurs in the $\mathrm{N}$ of the study area, and runs across the SE corner of Mull. The study area extends from the SW end of the island of Lismore to the outer Firth of Lorn, W of the Island of Jura (Fig. 1). This area is considered a priority region for hydrographic mapping, having seen an increase in maritime activities such as aquaculture, marine renewables and tourism. The region is also considered a Special Area of Conservation, based primarily on the inshore rocky reef habitats of the central and eastern areas, informally termed the Slate Islands, which are considered an area of diverse and pristine habitat. Since 2014, the entire Firth of Lorn is part of the Marine Protected Area (MPA) network.

The INIS Hydro project (Ireland, Northern Ireland and Scotland Hydrographic Survey) was an EU-funded project to map a number of 'priority areas' between Northern Ireland, Eire and Scotland. This study presents a new geological interpretation of the region based on the new multibeam survey. The survey has aided in identifying hitherto unknown seabed outcrops and structures in the Firth of Lorn, and confirmed regions of previously speculative sediment mobility. Whilst many of the features and outcrop occurrence of bedrock lithologies have been inferred before (e.g., Anderton 1988; Fyfe et al. 1993), the addition of the new survey information, specifically high-resolution multibeam echo sounder data, has revealed the seabed morphology and structure.

Prior to this study, the submarine geology of this region of the UKCS was relatively unknown, with little published work. Eden et al. (1971) carried out two traverses with a manned submersible observing Tertiary dykes and the cliff here referred to as the Insh Fault. Several authors, including Dobson \& Evans (1974) and Binns et al. (1974), investigated the area to the SW between Islay and Mull but it was Barber et al. (1979) 

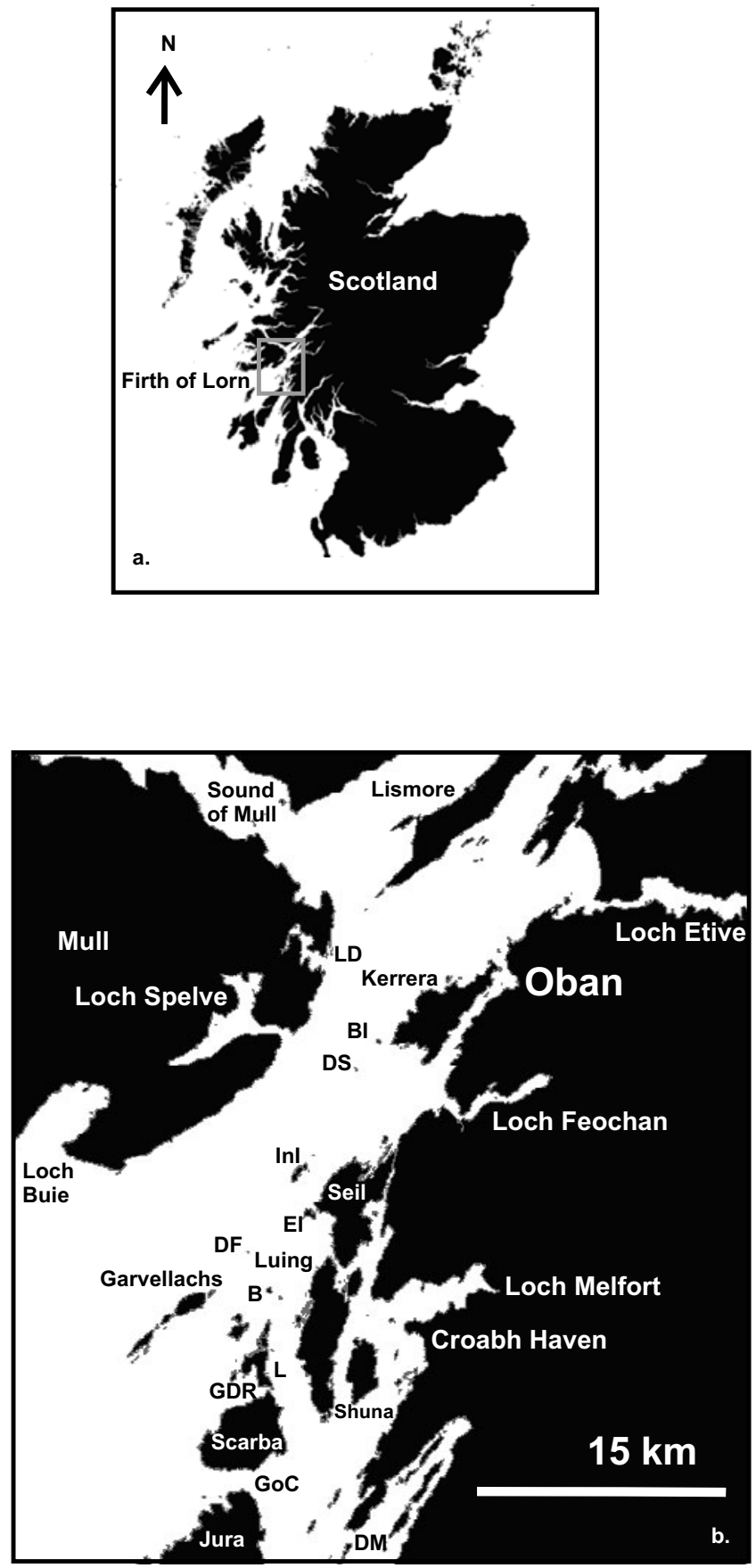

Figure 1 (a) Location map of the INIS Hydro survey, Firth of Lorn, western Scotland, UK. (b) Close-up of study location showing main inshore areas referred to in the text. Abbreviations: $\mathrm{B}=$ Belnahua; $\mathrm{BI}=$ Bach Island; $\mathrm{DF}=$ Dubh Fheith; $\mathrm{DM}=$ Dorus Mor; $\mathrm{DS}=$ Dubh Sgeir; EI = Easdale Island; GDR = Grey Dogs Race; GoC = Gulf of Corryvreckan; $\mathrm{InI}=$ Insh Island; $\mathrm{L}=$ Lunga; $\mathrm{LD}=$ Loch Don.

who produced the first detailed sea bed map to include the Firth of Lorn. This was based on grab and dive sampling, together with shallow seismic, and showed a large area of ORS sediments and lavas overlying the Dalradian basement. These data were incorporated, with modifications, in the British Geological Survey 1:250,000 map (British Geological Survey 1987). A framework for the Quaternary stratigraphy of this part of the Scottish shelf was presented by Davies et al. (1984). A very useful review of the geological evolution and stratigraphy of the Malin Shelf, to the west of the Firth of Lorn, is given by Fyfe et al. (1993).

\section{Regional setting and geological history}

The Firth of Lorn is geologically diverse, containing rocks ranging in age from the Precambrian to sediment cover preserving evidence of the last Quaternary glaciation (Devensian) (see Table 1) (British Geological Survey 1987). Of particular geological interest are the rocks on the Garvellachs, which provide the best evidence of Precambrian glaciation in the British Isles, and some of the best outcrops globally (Arnaud $\&$ Fairchild 2011). The solid geology of the Firth of Lorn is dominated by late Precambrian rocks (Neoproterozoic) of the Dalradian Supergroup, composed of slates, phyllites, quartzites, limestones and schists, overlain unconformably by the sediments and lavas that make up the local Lower Old Red Sandstone succession (British Geological Survey 1987). These rocks are a microcosm of the Caledonian evolution of Scotland, the Dalradian rocks having been deposited as the LaurentianBaltic crust was stretched prior to the formation of the Iapetus Ocean, the ORS being formed following uplift and erosion of the mountain chain formed as that ocean was destroyed. The Dalradian rocks include parts of the Appin and Argyll Groups (Table 1) which, as well as the glacial deposits of the Port Askaig Tillite, include metasediments that were deposited in a range of shallow shelf to deep water basinal environments (Anderton 1985).

The overlying Old Red Sandstone is composed of sandstones, conglomerates and breccias, and the Lorn Plateau Lavas, a calc-alkaline suite dominated by basaltic andesites and andesites (Trewin \& Thirlwall 2002). Small areas of other formations also occur locally in the Firth of Lorn, including some Jurassic-age sediments around the coast of Mull. Paleocene dolerite dykes and sills also locally occur across the region, (Stephenson \& Gould 1995).

The Firth of Lorn experienced a number of glaciations throughout the Quaternary. The last glaciation, the Devensian $(\sim 110-12 \mathrm{ky})$, produced ice flow mainly towards SW and extending to the shelf break. Full deglaciation started around $19 \mathrm{ky}$ and was interrupted by numerous still-stands and readvances in many parts of the western UK shelf (Ó Cofaigh et al. 2012). During the Younger Dryas stadial ( 12.8-11.5 ky) there was a return to full glacial conditions, but ice was more restricted to the fjords (McIntyre \& Howe 2010; McIntyre 2012).

The study area also encompasses the Corryvreckan whirlpool, a strong tidal race between the islands of Scarba and Jura, where maximum water speeds of $4.5 \mathrm{~ms}^{-1}$ have been recorded (A. Dale pers. comm. 2014). Such strong tidal flows have a profound influence on sediment movement in the vicinity of the whirlpool; and the wider effect of sediment mobilisation is manifest by the general absence of fine-grained sediments across the southern region of the survey and the predominance of coarse-grained sediments and sediment-free rock platforms and exposed rock surfaces. Generally, the sea lochs contain thick sequences of muds, commonly gasified with pock marks revealing gas or fluid flow at the seabed, whilst the majority of the bathymetry of the Firth of Lorn is revealed as a series of linear to gently curved, fault- and stratigraphically-controlled deeps, producing depositional basins surrounded by bedrock highs. This study presents an overview of the geomorphology of the Firth of Lorn and shows how vital this type of data can be to understanding the submarine geology and depositional processes in a glaciated inshore region of the UKCS.

\section{Survey method}

Seabed bathymetric data were collected by the Scottish Association for Marine Science (SAMS) using a multibeam echosounder (MBES) during 2012-2013 as part of the INIS Hydro 
Table 1 Stratigraphy of the submarine geology of the Firth of Lorn (adapted from Anderton 1985; Stephenson \& Gould 1995)

\begin{tabular}{|c|c|c|c|}
\hline $\begin{array}{l}\text { Geological } \\
\text { Period }\end{array}$ & Rock Units & Lithologies & Occurrence in the Firth of Lorn \\
\hline Tertiary & Paleocene & $\begin{array}{l}\text { Basaltic and } \\
\text { intermediate } \\
\text { lavas; basaltic } \\
\text { dykes and sills }\end{array}$ & $\begin{array}{l}\text { Mull; and as minor intrusives throughout } \\
\text { the region }\end{array}$ \\
\hline Cretaceous & $\begin{array}{l}\text { Upper } \\
\text { Cretaceous? }\end{array}$ & $\begin{array}{l}\text { Limestones; } \\
\text { sandstones }\end{array}$ & Postulated occurrence on E Mull \\
\hline Jurassic & Lower Lias & $\begin{array}{l}\text { Shales; } \\
\text { limestones; } \\
\text { sandstones }\end{array}$ & E Mull \\
\hline $\begin{array}{l}\text { Permo- } \\
\text { Triassic }\end{array}$ & $\begin{array}{l}\text { New Red } \\
\text { Sandstone }\end{array}$ & $\begin{array}{l}\text { Sandstones; } \\
\text { breccias }\end{array}$ & Mull and Movern \\
\hline $\begin{array}{l}\text { Silurian } \\
\text { (Devonian) }\end{array}$ & $\begin{array}{l}\text { Old Red } \\
\text { Sandstone }\end{array}$ & $\begin{array}{l}\text { Basaltic and } \\
\text { intermediate } \\
\text { lavas; } \\
\text { sandstones; } \\
\text { mudstones; } \\
\text { conglomerate; } \\
\text { breccia }\end{array}$ & $\begin{array}{l}\text { Extensive; especially Kerrera, Oban and } \\
\text { surrounding region. Outliers in the Firth } \\
\text { of Lorn }\end{array}$ \\
\hline \multirow[t]{2}{*}{ Precambrian } & Dalradian & Metasediment & Extensive; Jura, Scarba and Slate Islands \\
\hline & $\begin{array}{l}\text { Moine (W } \\
\text { of Great } \\
\text { Glen Fault } \\
\text { only) }\end{array}$ & Gneiss & Morvern \\
\hline
\end{tabular}

project on behalf of the Maritime and Coastguard Agency (MCA). Most of the survey is identified as Hydrographic Instruction 1354 and covers an area of approximately $553 \mathrm{~km}^{2}$, from the west coast of Jura in the $\mathrm{S}$ to the entrance to the Sound of Mull in the N (Fig. 2). SAMS vessel RV Calanus utilised a hull-mounted Reson Seabat 7125 dual-frequency (200 and $400 \mathrm{kHz}$ ) multibeam. The system utilises 256 and 512 beams across a $120^{\circ}$ swath, providing data coverage approximately three times water depth and a bathymetric resolution, depending on water depth, of up to a few centimetres. Sound velocity data were collected from a hull-mounted Reson SVP 71 sound velocity probe. Attitude, heading and positional data were collected using an Applanix POSmv to a positional accuracy of $<1 \mathrm{~m}$. All data were compiled on board using Reson PDS software. Inshore, shallow water surveys were collected by the British Geological Survey (BGS) vessel RV White Ribbon using a Kongsberg EM3002D $300 \mathrm{kHz}$ multibeam. Conductivity, temperature and density (CTD) dips were obtained during the survey using a Seabird 19+ instrument. Water column velocity profiles were prepared using SeaTerm software and converted into ASCII files.

Post-acquisition data processing was conducted by SAMS. The data were imported, cleaned and shoal surfaces prepared using basic mean bathymetric and combined uncertainty bathymetric evaluation (CUBE) grids with manual and standard deviation filtering. Subsequent data manipulation and visualisation were conducted by the British Geological Survey, Edinburgh, using Caris HIPS and SIPS and Fledermaus software. GeoTiffs of the data layers were imported into ArcGIS v.10.2, where geomorphological classification and mapping were conducted, via direct digitising of features (Fig. 3).

The survey area was sampled using a Van Veen grab, collecting approximately $0.1 \mathrm{~m}^{2}$ of seabed sediments at each grab to inform the seafloor sediment interpretations (Crump 2013).

\section{Submarine geomorphology}

\subsection{Solid geology of the seafloor}

3.1.1. Rock platforms. The Firth of Lorn is characterised by a series of submarine rock platforms that are sufficiently resistant to have survived glacial erosion. These rock platforms form isolated bathymetric highs and coastal rock platforms with water depths typically $<50 \mathrm{~m}$. The main rock platforms occur in the central survey area, and include the islands of Insh, Dubh-fheith, Bach and Dubh Sgeir (Fig. 4a). Typically, these islands are surrounded by extensive $\left(<5-10 \mathrm{~km}^{2}\right)$ submarine rock platforms, in some cases with a linear or polygonal aspect, which are composed of Old Red Sandstone lavas (Insh, Bach Island and Dubh Sgeir) or Dalradian metasediments. Across these platforms run resistant SE-NW-trending, linear ridges $(5-30 \mathrm{~m}$ wide), surrounded by glacially-scoured linear 


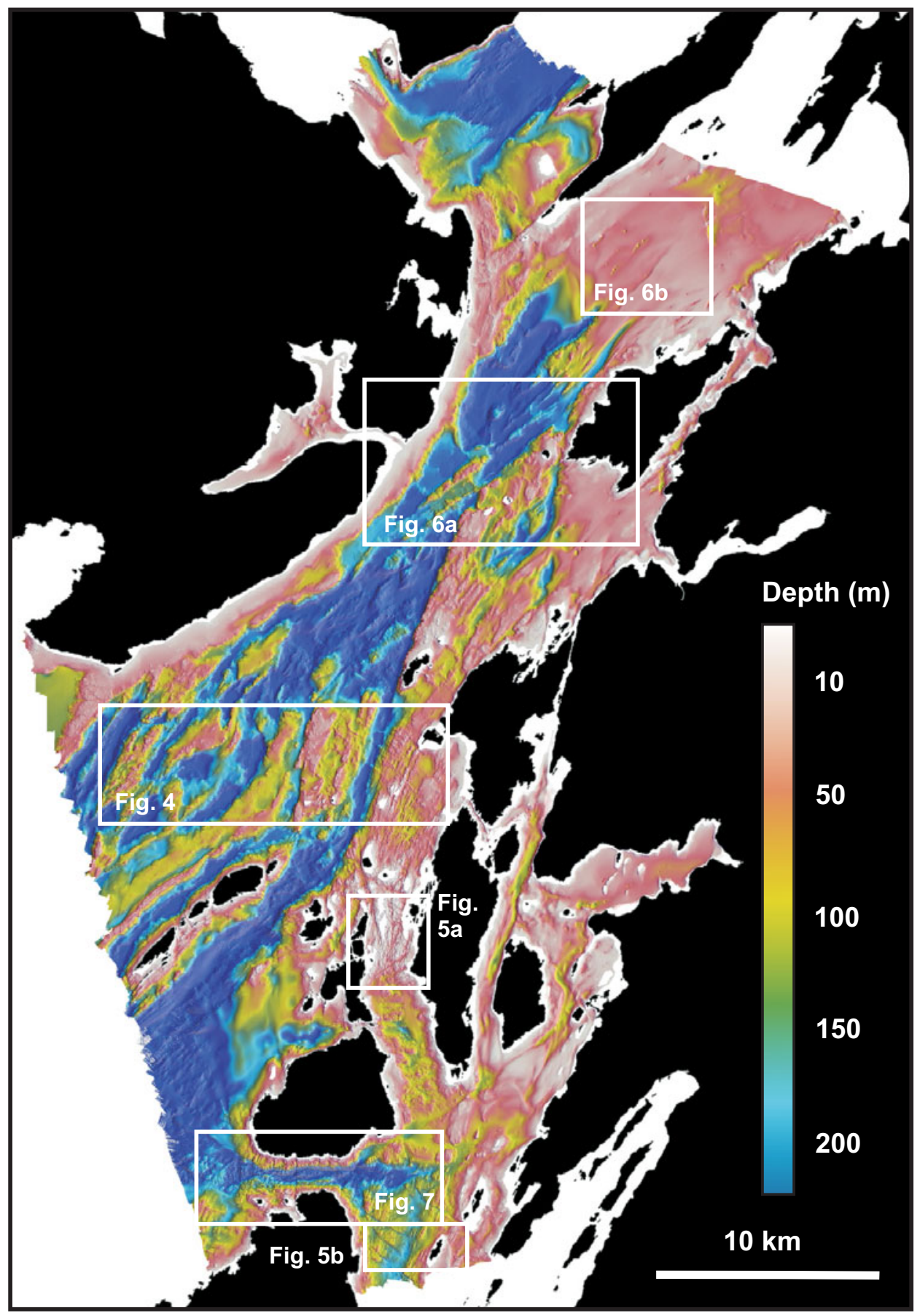

Figure 2 Submarine bathymetry of the Firth of Lorn, derived from INIS Hydro multibeam echo sounder surveys (2012-2013). Outlined areas show locations of Figures 4-7.

basins trending SW-NE (just E of Fig. 4a). These ridges are inferred to be igneous intrusives of Tertiary age. Inshore, coastal rock platforms also occur, the best example being found at the SW of the survey area, off the coast of Mull. Here, SE of Loch Buie, 5-7 $\mathrm{km}^{2}$ of exposed rock protrudes SW in water depths of $20-70 \mathrm{~m}$. As with other bedrock platforms across the region, the outcrop bathymetry has a characteristic wedge-shape, narrowing from $1.2 \mathrm{~km}$ wide to $<0.5 \mathrm{~km}$ at the seaward end.

3.1.2. Linear ridges - sinuous and arrow-head morphologies. Narrow $(<100 \mathrm{~m})$ linear ridges trending SW-NE occur to the $\mathrm{N}$ of the Garvellach islands (Fig. 4c, d). The most prominent is a $9 \mathrm{~km}$-long sinuous ridge extending SW from the submarine rock platform surrounding and originating from Dubh-fheith island (Figs 2, 4c). Other less well defined ridges occur to the NW and are composed of either Dalradian Appin Group or Old Red Sandstone rocks (Fig. 4). In contrast, a complex of rock ridges also occurs between the islands of Kerrera and Mull, in the central and NE region of the survey (Fig. 6a). Here the ridges extend for $3-5 \mathrm{~km}$ and display a unique, characteristic arrow-head shape, being consistently wider $(100-300 \mathrm{~m})$ to the NE and narrowing to $<50 \mathrm{~m}$ to the SW. These ridges are probably tight folds of Appin Group Dalradian rocks, the arrowhead shape being the result of the fold axes plunging towards the SW.

3.1.3. Minor igneous intrusives. Where the bedrock is not buried beneath sediment cover, 5-30 m-wide resistant rock ridges up to $6 \mathrm{~km}$ long are often visible, most with an E-W to ESE-WSW trend. These are interpreted as dykes of Tertiary (Palaeocene) age. In some cases (e.g., across the $\mathrm{N}$ of 

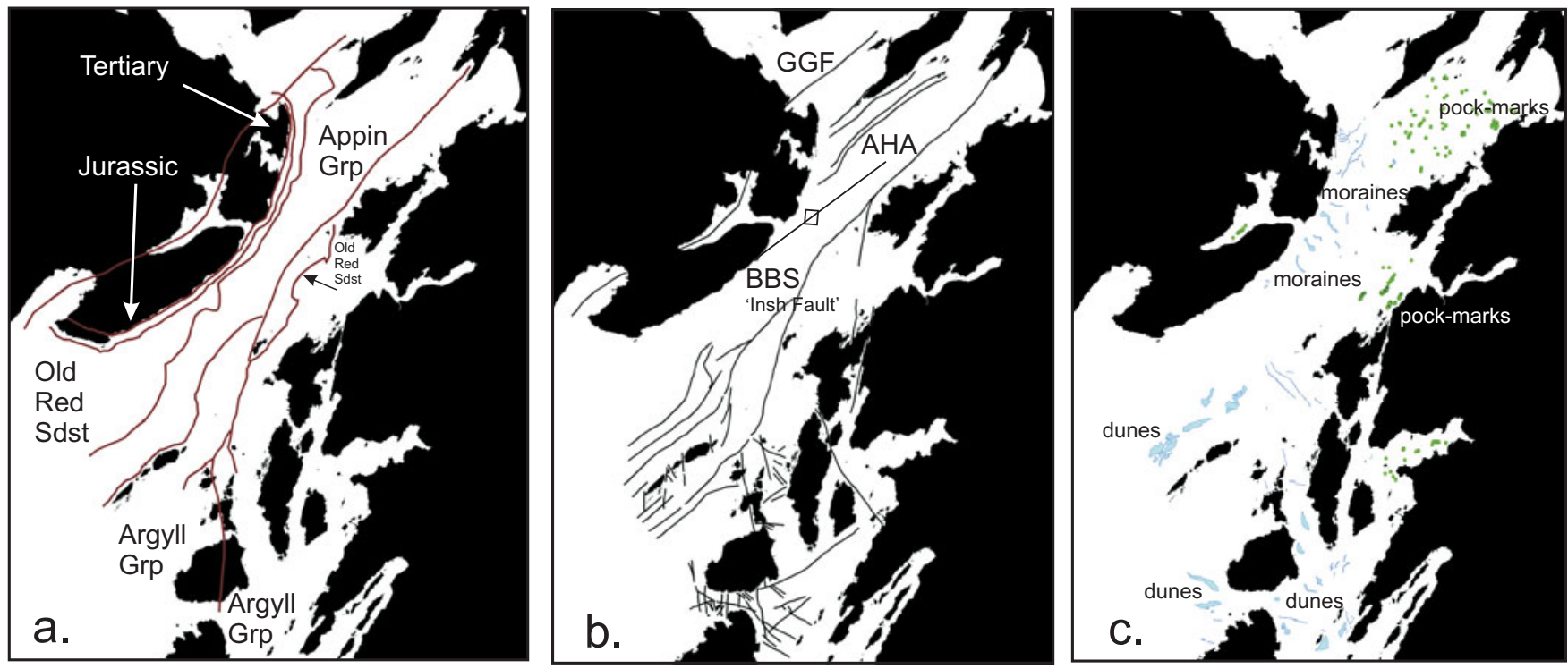

Figure 3 Firth of Lorn: (a) principal stratigraphic elements; (b) principal structural elements; (c) examples of the main geomorphological elements. Abbreviations: AHA = Airds Hill Anticline; BBS = BallachulishBenderloch Slide (aka 'Insh Fault'); GGF = Great Glen Fault; Grp = Group; Sdst = Sandstone.

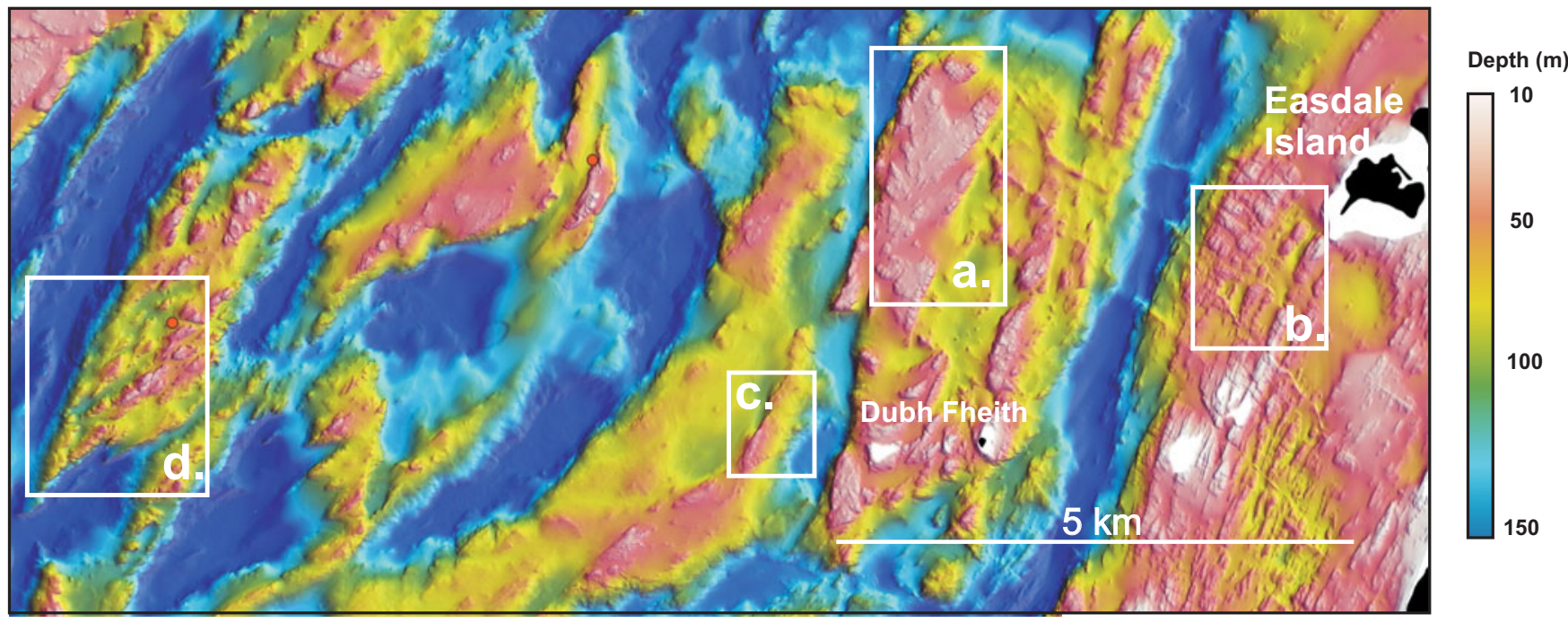

Figure 4 (a, b) Examples of exposed rock platforms: (a) in the Dalradian Port Askaig Tillite; (b) in the Dalradian Easdale Slates. (c) Linear ridge in the Dalradian, Appin Group. (d) Ridges with arrow-head morphology in the Old Red Sandstone. Red circles denote Barber et al. (1979) dive sites. For location, see Figure 2.

the Sound of Jura, and around Easdale, Seil and Luing) these can be traced onshore and their origins readily identified (Fig. $5 \mathrm{a}, \mathrm{b})$. In some occurrences, such as the swarm of four dykes SW of Easdale Island, the dykes are coincident with sediment ridges, interpreted as glacial moraines, suggesting that they may have had an influence in slowing or pinning ice movement leading to glacial sediment deposition (see Fig. 4b).

3.1.4. Submarine cliffs. The Firth of Lorn region includes part of the submarine extent of the Great Glen Fault (GGF) complex (Fyfe et al. 1993). The GGF occurs onshore across the SE of Mull, so it is not unexpected that the survey area includes numerous examples of major faults exposed on the seabed. Many of these faults offset the outcrop geology, or have a seabed expression of a few metres relief. The most impressive and extensive lineament occurs across the central region of the survey, to the $\mathrm{N}$ and $\mathrm{S}$ of Insh Island. It extends, almost continuously, for approximately $24 \mathrm{~km}$, providing a submarine cliff with a maximum height of over $150 \mathrm{~m}$, notably $\mathrm{W}$ of Insh where water depths drop, almost vertically from
$20 \mathrm{~m}$ to $180 \mathrm{~m}$ over a horizontal distance of $<50 \mathrm{~m}$ (Fig. 2). The presence of this feature is very obvious on Admiralty charts; a submersible dive over it was described by Eden et al. (1971) and it is shown as a fault on the map of Barber et al. (1979, fig. 2) who discussed Holgate's (1969) suggestion that it could be a splay of the Great Glen Fault. Anderton (1988), on the other hand, used this lineament to connect the Benderloch-Ballachulish Slide in Benderloch, to the NE of the survey area, with the Scarba Fault on Scarba, on the grounds that both these faults originated as Dalradian syndepositional faults that defined the edge of the basin in which the Easdale Slates were deposited. The new bathymetry shows that a connection to the NE with the Benderloch-Ballachulish Slide is quite possible, although unproven, as it passes under a thick sediment cover north of Kerrera. The extension of the structure southwards is more complex than previously shown and it may split, if it is a fault, into several splays which run both E of Lunga and S of the Garvellachs, as well as through Lunga into Scarba. 


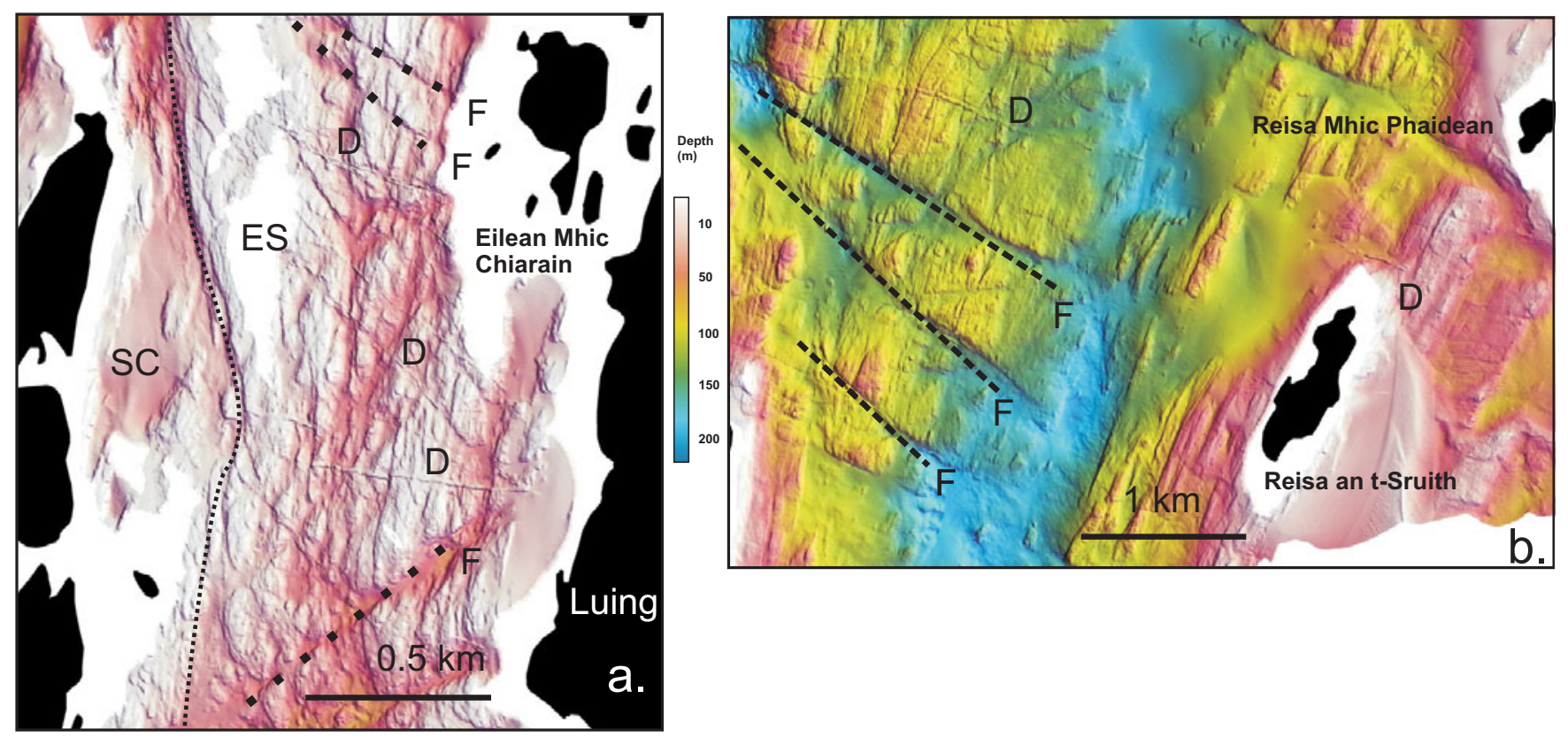

Figure 5 Seabed faulting (F): (a) in the Sound of Luing; (b) east of the Gulf of Corryvreckan, between the mainland and Jura. Also indicated are igneous intrusives (D: dykes) of Paleocene age (basaltic). The dashed line in (a) denotes the approximate boundary between the Scarba Conglomerate (SC) and the Easdale Slates (ES). For location, see Figure 2.

Less visually striking are the structures extending across the Gulf of Corryvreckan between Scarba and Jura (Figs 5b, 7). Here the current-swept seafloor is composed of Dalradian Jura Quartzite and, although there is a complex fracture pattern, which has produced the weakness in this very hard rock that has been exploited by glaciers to form the Gulf, there is no evidence for any significant fault offset.

3.1.5. Exposed rock surfaces. The main region of bare rock coincides with the occurrence of the Easdale Slates surrounding the islands of Luing, Seil, Easdale and adjacent to the islands $\mathrm{N}$ of Scarba. It is unsurprising that this extensive (approximately 20-30 $\mathrm{km}^{2}$ ) region is exposed, given the proximity of the strong tidal streams generated by the Gulf of Corryvreckan and the restricted passages, enhancing tidal flow between the islands. The influence of the Gulf on sedimentation is described below, but the exposed bedrock of the Sound of Luing, Easdale Bay and further S at the northern end of the Sound of Jura, reveals the structural fabric of the metasediments (Fig. 5a, b). The contact between the Easdale Slate and the Scarba Conglomerate is shown on the survey data, where the more massive quartzites contrast markedly with the foliated slates and phyllites (Fig. 5a). Locally, the slate is interrupted by minor intrusions visible as resistant SE-NW-trending ridges. The origin of the exposed rock surfaces is directly linked to strong tidal flows, being coincident with the main tidal streams across the Gulf of Corryvreckan and to the $\mathrm{N}$ with the Little Corryvreckan, or Grey Dogs Race.

\subsection{Glacial features and Holocene sediments}

3.2.1. Rock basins. There are a number of rock basins within the survey area, here defined as an enclosed depositional region with water depths of $>150 \mathrm{~m}$. These basins occur between Lismore and Movern, Kerrera and Mull, and in the central Firth of Lorn ( $\mathrm{S}$ of Loch Spelve) and SE of the Garvellachs (Fig. 2). The basins are complex in shape and defined by the rock platforms and ridges that surround them. The basin floors are not smooth, but interrupted by rock outcrops, ridges and other bedrock features. They are limited in areal extent, being $<5 \mathrm{~km}^{2}$ and all are confined, with the exception of one SE of the Garvellachs, which only lies partially within the survey coverage. Grab sampling has recovered finegrained sandy mud and clayey mud from these basins. Their origin is complex, being linked to both the geological structure of the bedrock of the Firth and its glacial history.

3.2.2. Bedrock megaflutes and streamlines. Across the survey the effects of glacial erosion are widespread. In the region $\mathrm{S}$ of the Garvellachs and $\mathrm{E}$ towards the islands of Lunga there are bedrock ridges, which have become elongate and smoothed. A similar region of megaflute preservation is $\mathrm{W}$ of Luing, with the prevailing trend suggesting ice transport from the E from Loch Melfort. Extensive streamlines noted from previous surveys in other areas (Stoker et al. 2006; Howe et al. 2012) are not readily identified in the Firth of Lorn, except for the examples given above. Two main explanations can be given. The first is that the Firth of Lorn was inboard of the 'onset' of ice streaming and such structures should appear more offshore. Alternatively, the absence can be due to a preservation issue, either during late deglaciation, or from marine erosion. Moreover, the evidence for pervasive sub-glacial erosion is somewhat masked by the prevailing strike of the Dalradian metasediments being coincident with the assumed direction of ice transport. The resulting effect is one of the linear ridges and basins morphology throughout the survey. Where the fabric of the exposed solid rocks geology is not in a SW-NE orientation (e.g., the dykes through the slates and Old Red Sandstone), a smoothed, roche moutonnée morphology is apparent.

3.2.3. Elongate rock drumlins. A number of smoothed, linear bedrock ridges occur across the central and southern part of the survey area. Typically, these have an elongate or drumlin style morphology and are smaller and less extensive than the rocky arrow-head ridges described earlier. These features are interpreted as wholly glacial or, specifically, subglacial in origin, and they occur extensively across the surveyed area, with the best examples recorded from the area $\mathrm{S}$ of the Garvellachs, where the strike of the Dalradian metasediments is coincident with the NE-SW orientation of the basin (Fig. 3b). The outcrops have become smoothed and 

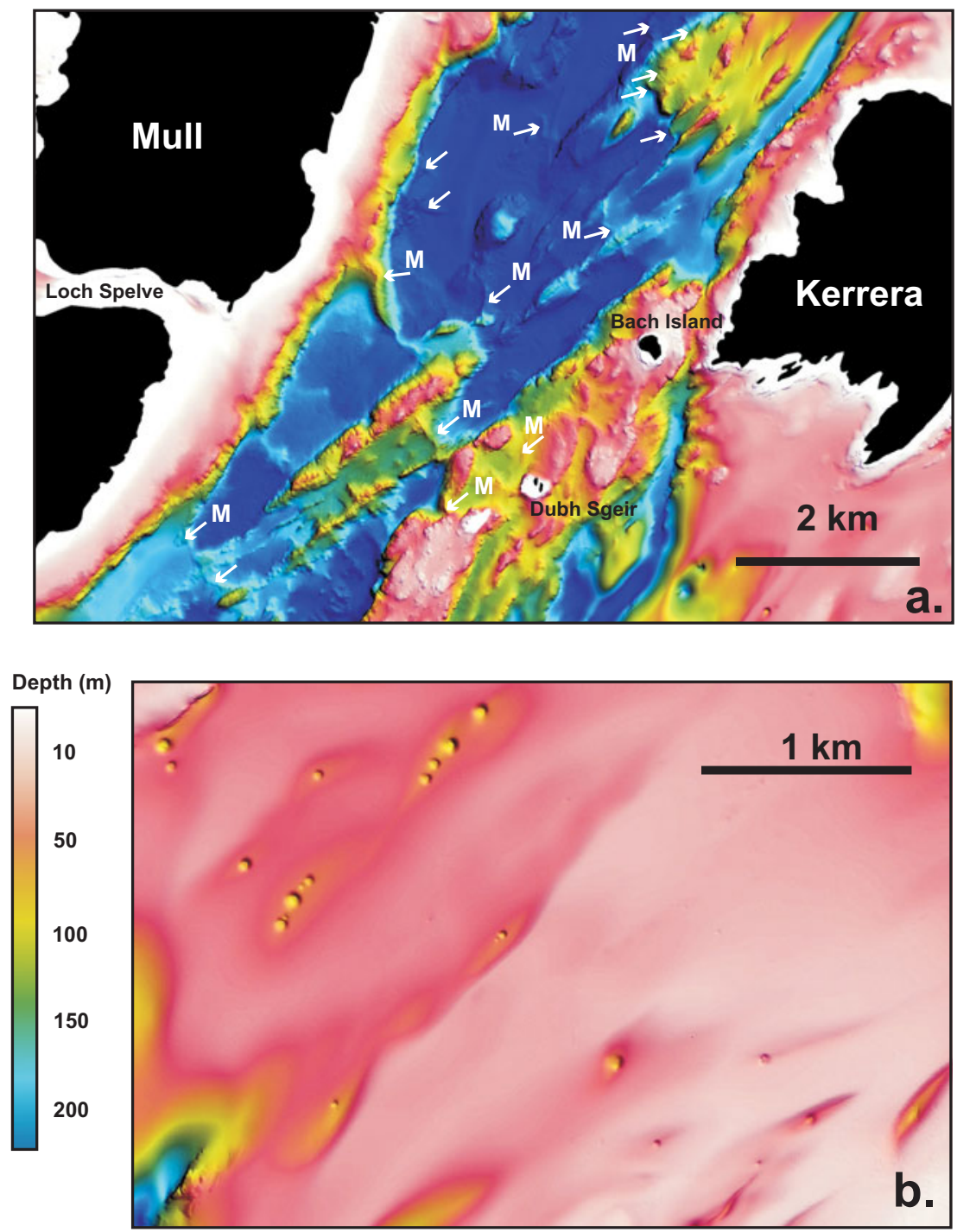

Figure 6 (a) Location of numerous glacial moraines (arrowed 'M') between Kerrera and Mull. (b) Thick fine-grained post-glacial sediment accumulation with gas-escape pock marks. For location, see Figure 2.

elongated, $0.5-0.7 \mathrm{~km}$ long and $<30 \mathrm{~m}$ wide. This region is also subject to the tidal flows of both the Grey Dogs Race and Corryvreckan; these high-energy flows keep the basin relatively sediment-free and reveal the elongate and streamlined rock outcrops which are presumed to be the result of sub-glacial erosion.

3.2.4. Moraine ridges and moraine complexes. Linear sediment ridges, interpreted as glacial moraines, occur in a number of areas in the Firth of Lorn. The highest and longest is a 50 m-high sediment bank extending $>3 \mathrm{~km}$ across the Firth of Lorn from Mull, south of Loch Don (Fig. 6a). This moraine is the largest of a series of moraines occurring $\mathrm{NW}$ of Bach Island between Kerrera and Mull and was first noted by McIntyre (2012) and interpreted as the offshore extension of the onshore Loch Don moraine of Younger Dryas age (11.5$12.8 \mathrm{ka}$ ). The moraines are sinuous and traverse the rock outcrops on the floor of the basin in water depths of up to $200 \mathrm{~m}$. In total, 12 moraines occur in this area, where the Firth of Lorn is at its narrowest, and $<2 \mathrm{~km}$ across the deep water basin between two rock platforms extending from Mull and Kerrera. This distribution suggests that glacial ice was constrained and topographically 'pinned', resulting in the deposition of the moraine complex. Further to the SW, adjacent to the island of Easdale, a further three moraines occur, although these are smaller $(<20 \mathrm{~m})$ and shorter $(<0.5 \mathrm{~km})$. These fea- tures are related to the positions of dykes that are orientated NW-SE in this region and are confined to the deeper water channel in water depths of $\sim 70-100 \mathrm{~m}$. Grab sampling across all these ridges confirms their composition as a diamict, containing principally rounded boulders and sandy mud.

3.2.5. Linear sediment troughs. In some areas of thick, fine-grained sediment (e.g., $\mathrm{N}$ of Kerrera, in Loch Melfort and Loch Shuna) the superficial sediments are crossed by narrow linear troughs, typically $<2 \mathrm{~km}$ in length and $<200$ $\mathrm{m}$ wide and with a wide depth range, below the surrounding seabed, of 10-120 m. The largest example occurs off NW Kerrera, where a $2 \mathrm{~km}$-long continuous trough occurs with a $\mathrm{NE}-\mathrm{SW}$ orientation. At its SW end, the trough opens out onto the floor of a $100 \mathrm{~m}$-deep basin, but is constrained at its southerly flank by rock outcrops. The occurrence of the rock outcrop might indicate a geological control on the trough's origins, with tidal flow becoming focused by the rock outcrops to produce non-deposition, or even erosion of the sediments. Toward the NE, the tidal energy is lessened and the troughs are shallower. Other smaller troughs occur between Lismore and Oban. These all have an ESE-WNW and WSW-ENE orientation, approximately parallel to the coast of Kerrera, suggesting that these also might have a sub-seabed geological control related to the strike of the underlying solid rocks. At the northern limit of the Sound of Jura, offshore from Croabh 


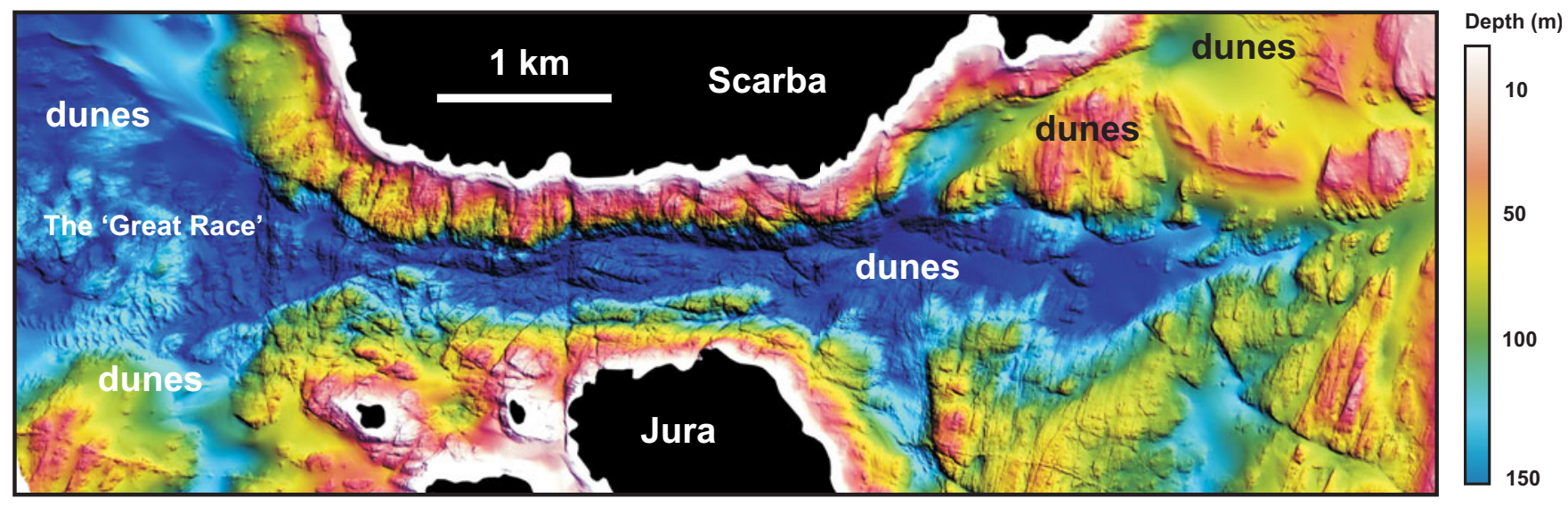

Figure 7 Submarine dunes within the Gulf of Corryvreckan, between the islands of Jura (S) and Scarba (N), illustrating the linear dunes to the north of the Great Race, the extensive field of dunes developed beneath the Great Race. Western Corryvreckan and eastern Corryvreckan dunes are interpreted as banner bank developments. The N-S-trending features are epidiorite dykes; the NE-SW-trending features are bedding surfaces; the $\mathrm{E}-\mathrm{W}$ - and SE-NW-trending features are interpreted as small faults and fractures. For location, see Figure 2.

Haven, similar linear sediment troughs occur. Here, the subseabed control appears to be fault- or fracture-related, as the troughs are in line with the noted seabed expression of features extending from the Gulf of Corryvreckan within both the Jura Quartzite and Easdale Slates. These troughs are relatively short $(<1 \mathrm{~km})$ and their amplitude is $<10 \mathrm{~m}$ deeper than the surrounding 30-50 m-deep seabed. Between the island of Shuna and Croabh Haven, a complex of linear sediment troughs mimics the presumed location of sub-seabed faults, extending across the seabed and into the mainland.

3.2.6. Submarine dunes. As described earlier, the Firth of Lorn is the location of some of the strongest tidal flows in the UK, notably the localised flows of the Gulf of Corryvreckan and Grey Dogs Race. It is unsurprising that the seabed surrounding these two channels exhibits areas of submarine dune formation, all assumed to be produced by a confined, strong tidal flow becoming unconfined, leading to turbulence and vorticity, with the decline in velocity leading to deposition of the transported sediment load.

The Gulf of Corryvreckan shows two regions of submarine dunes, E and W of the Gulf (Fig. 7). The largest dune complex occurs NW of the Gulf extending from the Scarba shoreline, in $60-150 \mathrm{~m}$ of water, $1.7 \mathrm{~km} \mathrm{NW}$ towards the Garvellachs. The dune field rises to $25 \mathrm{~m}$ above the surrounding seabed and is up to $200 \mathrm{~m}$ wide. The dune crest is formed by a series of five lunate shaped narrow ridges, each one approximately $150 \mathrm{~m}$ long. The composition of the dune, sampled by grab, is of coarse to very coarse sands and shelly sands. Its location may represent the limit of the turbulent eddies generated in the gulf, and referred to as the Great Race. Occurring approximately $2 \mathrm{~km} \mathrm{E}$ of the Gulf, in $50 \mathrm{~m}$ water depth, are two isolated banks composed of shelly sands, both with an extent of $<1.5 \mathrm{~km}^{2}$ and an asymmetrical, lozenge shape. The westernmost bank displays a linear form, and superimposed on its top is a single, curving dune crest, $1.5 \mathrm{~km}$ long with three individual crests extending from its NW margin, each having an $\mathrm{E}-\mathrm{W}$ orientation and each $<0.5 \mathrm{~km}$ long. The eastern bank is more compact, and occurs $<1 \mathrm{~km} \mathrm{NE}$ from the western bank and, similar to its neighbour, has a single dune crest, orientated $\mathrm{N}-\mathrm{S}$ from which three individual crests are produced, extending $50-100 \mathrm{~m}$ in a NW-SE direction. These forms of sand bank and dune with tree-like or trellis morphology have not been observed anywhere else within the survey area. Their origin must be assumed to be linked to the higher sediment supply, E of the Gulf (being closer to the sea loch environments of the mainland), and to the complex physiography contained in this small region. Here, the seabed of Easdale Slate is faulted into narrow channels, and the funnelling action of the tides may have combined to both capture and winnow the sediment, generating the turbulence necessary to produce the observed dune and dune crest morphologies.

The Grey Dogs Race is a narrow (approximately $100 \mathrm{~m}$ wide) channel between the islands of Scarba and Lunga. Locally, tidal flows in excess of those of the Corryvreckan can occur, although the channel is narrower and much shorter $(<800 \mathrm{~m})$. The main dune development occurs $\mathrm{E}$ of the channel, and on the E side of the Sound of Luing, adjacent to the Luing shoreline, in $30-50 \mathrm{~m}$ of water. The dune field is again developed in coarse sands and is diamond-shaped, with an area of $1 \mathrm{~km}^{2}$. In contrast to the Corryvreckan dunes, this region has no well-developed crest, but a $<100 \mathrm{~m}^{2}$ patch of sand waves at its SW edge.

One of the most striking observations from the entire survey is the occurrence of an extensive field of dunes $\mathrm{W}$ of the Corryvreckan. Here, a $1.5 \mathrm{~km}^{2}$ dune field occurs in water depths of around 100-150 m. Crest-to-crest wavelengths are $20-120 \mathrm{~m}$ and wave heights are approximately 3-10 m from the surrounding seabed. The dunes form continuous or semicontinuous sinuous ridges $0.75-1.2 \mathrm{~km}$ long, in an approximate $\mathrm{N}-\mathrm{S}$ orientation. As with the dune ridge to the north, this dune field occurs beneath the main turbulence of the Great Race, and its position is assumed to be the product of the confined, high flows of the Gulf becoming unconfined and depositing coarse sands, previously held in suspension, onto the sea floor.

Two smaller $\left(1 \mathrm{~km}^{2}\right)$ areas of dunes, locally rippled, occur at the SE corner of the survey, close to the Craignish Peninsula at the $\mathrm{N}$ end of the Sound of Jura. These two areas of dunes are similar to those in the Sound of Luing, being lozenge shaped and formed in the lee of two islands (Reisa an t-Sruith and Reisa Mhic Phaidean, Fig. 5b). The sediment was confirmed to be coarse sand (Crump 2013) and has formed on the eastern side of the islands, in the lee from the main tidal flow of the Corryvreckan and the confluence of flows from the race generated by the Dorus Mor to the $\mathrm{S}$ of the survey area.

The dunes observed in the Firth of Lorn are typical 'banner bank' types (Shaw et al. 2012). These features form as a result of the turbulence at the boundary of unconfined flow produced by a bathymetric obstacle or passage.

3.2.7. Sea lochs and associated inshore basins. The fjordic landscape of indented sea lochs that characterises the $\mathrm{W}$ coast of Scotland is the most obvious evidence of the region's perva- 
Table 2 Principal stratigraphic elements of the Dalradian outcrops of the Firth of Lorn (adapted from Anderton 1985; Stevenson \& Gould 1995)

\begin{tabular}{|c|c|c|c|c|}
\hline Group & Subgroup & Formation & $\begin{array}{l}\text { Depositional } \\
\text { Interpretation }\end{array}$ & Subsidence History \\
\hline \multirow[t]{7}{*}{$595 \mathrm{Ma}$} & \multirow[t]{4}{*}{ Easdale } & $\begin{array}{l}\text { Craignish } \\
\text { Phyllites }\end{array}$ & Tidal flat & Basin filling \\
\hline & & & & \\
\hline & & Easdale Slate & Turbidite basin & \multirow{2}{*}{$\begin{array}{l}\text { Rapid subsidence } \\
\text { and basin filling }\end{array}$} \\
\hline & & $\begin{array}{l}\text { Scarba } \\
\text { Conglomerate }\end{array}$ & Turbidite basin & \\
\hline & \multirow{3}{*}{ Islay } & Jura Quartzite & Tidal shelf & \multirow{3}{*}{$\begin{array}{l}\text { Rapid subsidence } \\
\text { and rapid deposition }\end{array}$} \\
\hline & & $\begin{array}{l}\text { Bonahaven } \\
\text { Dolomite }\end{array}$ & Nearshore shelf & \\
\hline & & $\begin{array}{l}\text { Port } \quad \text { Askaig } \\
\text { Tillite }\end{array}$ & Glacial tidal shelf & \\
\hline \multirow{7}{*}{ Appin } & \multirow[t]{2}{*}{ Blair Atholl } & $\begin{array}{l}\text { Lismore } \\
\text { Limestone }\end{array}$ & $\begin{array}{l}\text { Outer shelf to } \\
\text { basin }\end{array}$ & Basin filling \\
\hline & & Cuil Bay Slate & Deep anoxic basin & $\begin{array}{l}\text { Slow subsidence } \\
\text { and basin deepening }\end{array}$ \\
\hline & \multirow[t]{4}{*}{ Ballachulish } & $\begin{array}{l}\text { Appin Phyllite } \\
\text { and Limestone }\end{array}$ & Shelf & \multirow{4}{*}{ Basin filling } \\
\hline & & Appin Quartzite & Tidal shelf & \\
\hline & & $\begin{array}{l}\text { Ballachulish } \\
\text { Slate }\end{array}$ & Deep anoxic basin & \\
\hline & & $\begin{array}{l}\text { Ballachulish } \\
\text { Limestone }\end{array}$ & Basinal & \\
\hline & Lochaber & Leven Schist & $\begin{array}{l}\text { Low energy shelf to } \\
\text { basin }\end{array}$ & Basin deepening \\
\hline
\end{tabular}

sive glacial history. In the Firth of Lorn, a number of significant sea lochs have been surveyed in the course of this study; notably, Loch Spelve (Mull), the area surrounding Shuna, including Loch Melfort, and Seil Sound. Also of note are extensive areas of inshore, shallow water $(<50 \mathrm{~m})$ which contain thick accumulations of muds, such as the area at the NE of the survey, between Oban and Lismore and the region $\mathrm{S}$ of Kerrera. In all these areas, the seabed is smooth and only locally interrupted by rock outcrops (e.g., Loch Melfort) or by buried sub-seabed ridges (e.g., SE of Lismore). These regions are supplied with fine-grained, organic-rich sediment via Holocene riverine input from Loch Etive and Loch Linnhe to the $\mathrm{N}$ and from Loch Feochan to the $\mathrm{E}$.

3.2.8. Pock marks. Pock marks are a ubiquitous feature of fine-grained depositional basins in inshore areas with a high organic loading from suspended sediment. In the sea lochs of the Firth of Lorn, pock marks are abundant, with the main areas being Loch Melfort, S of Kerrera, opposite the entrance of Loch Feochan and the main area between Oban and Lismore (Fig. 6b). Throughout all these areas, the occurrence of pock marks is evidence for extensive sub-surface gasified sediment. Fader $(1991,1997)$ and Judd \& Hovland (2007) describe gasified fine-grained sediment as a common feature of fine-grained sediments in inshore areas. The pock marks are $10-100 \mathrm{~m}$ in diameter and $10-20 \mathrm{~m}$ deep. They mostly occur in a linear arrangement, suggesting sub-surface gas migration along syn-sedimentary faults, or thicker accumulation of gasified sediments within the basins. The pock marks in Loch Melfort are subtle in relief, perhaps indicating they are inactive and now becoming infilled by sediment. Of note is the complete absence of pock marks in the main seaway of the Firth of Lorn, an indication of either coarser-grained sediment, an absence of sub-surface gas and/or absence of unconsolidated sediment.

\section{Bedrock and structural interpretation}

The main features of the bathymetry of the area are clearly a consequence of the bedrock geology. The Quaternary sediment cover is generally too thin to totally mask the bedrock geology, except at the NE edge of the survey, north and south of Kerrera, and in some of the sea lochs, such as Loch Melfort.

In order to describe the submarine bedrock geology from the bathymetric data, the survey area can be divided into three areas: (i) the area of well-defined ridges and troughs in the SW; (ii) the platform area east of the Insh Fault; and (iii) the rest of the area which includes the deeper water central section of the Firth and the NE area. The principal stratigraphic units referred to are summarised in Tables 1 and 2. 


\subsection{The southwestern area}

The geological structure of the string of islands stretching from the Garvellachs to northern Jura is relatively simple: the rocks dip SE at $30-40^{\circ}$ and consist of Dalradian metasediments - the Islay Limestone and Port Askaig Tillite on the Garvellach Islands and the Jura Quartzite on Jura and Scarba. Immediately to the NW of the Garvellachs are a series of well-defined ridges and troughs running parallel to the Garvellachs, which is the local strike direction. This pattern is interpreted as the result of differential erosion of more and less resistant units within the Appin Group, which underlies the Islay Limestone. By comparison with the known onshore successions in Appin and on Islay, the stratigraphic horizons most likely to be forming these features are the Appin Quartzite and the Ballachulish Limestone. The ridge and trough pattern can be followed for some distance to the $\mathrm{N}$ of the Garvellachs, where it swings towards a more north-north-easterly strike and becomes somewhat broken up by a fault zone. The Dubhfheith platform, NNE of the Garvellachs, is an extension of the Garvellachs ridge and is probably composed of the Port Askaig Tillite. The deep trough immediately to the SE of the Garvellachs, which then runs to the NNE, just W of the Insh Fault, could be the result of the erosion of the soft lithologies of the Bonahaven Dolomite, which overlies the Tillite on Islay but is not seen onshore in the Firth of Lorn area.

To the NW of these Appin Group features is another set of ridges and troughs with a more northerly trend. The bathymetric data across these ridges show a rubbly texture, although there are some large, smooth planar surfaces which can be interpreted as bedding planes. These dip towards the $\mathrm{W}$ or NW, and hence the succession youngs to the NW, in the opposite direction to that seen in the Dalradian. At the SW extremity of the survey area, what must be the stratigraphically lowest, ridge-forming unit appears to truncate the structure in the Dalradian, cutting across the lowest (i.e., most north-westerly) ridge in the Appin Group. This relationship is interpreted as an unconformity between the Dalradian and the Old Red Sandstone. The rubbly character of the ridges is similar to that seen on the E side of the Firth, where ORS lavas can be traced offshore from outcrops on the islands of Seil, Insh and Kerrera. Therefore, it is possible the ridges are composed of lavas with at least some sandstone and conglomerate, indicated by the large bedding surfaces, and the troughs are dominated by siltstones and mudstones. These suggestions are confirmed by the dive sites described by Barber et al. (1979), who recovered samples from four locations within this area composed of lavas, sandstones and conglomerates that were all interpreted as of Lower ORS age. Traced NE, these ridges run into the coastal platform that fringes SE Mull, and the ORS must continue at depth under the Tertiary lavas SE of the Great Glen Fault, as seen in the Loch Don anticline. Along the coast, a thin Jurassic unit lies between the ORS and the Tertiary lavas.

\subsection{The eastern area}

The onshore coastal areas, to the E of the Insh Fault, consist of ORS sediments and volcanics sitting unconformably on the Dalradian Easdale Slates. On the rock platform areas around the Slate Islands (Luing, Seil, Easdale, Belnahua, etc.), the seabed shows a distinctive 'folded and foliated' character, reflecting the relatively homogeneous nature of the Easdale Slates and their pronounced cleavage. Linear features, indicating NW-trending Tertiary dykes, are also well displayed here because they form positive features against the softer slates. In contrast, seabed areas adjacent to ORS outcrops on Seil, Kerrera and Insh Island show a rubbly texture, with any ridge-like features being on a larger scale than in the Easdale Slates and indications of Tertiary dykes being much sparser.
Determining the base of the ORS involves tracing the boundary between these two types of seabed character. This suggests that the ORS forms one ridge extending northwards from Insh Island to Kerrera, bounded to the $\mathrm{W}$ by the Insh Fault, and another which extends northwards from Seil, a short distance towards Kerrera.

\subsection{The north and central areas}

The submarine geology of the area between Lismore and Oban can be interpolated from onshore information. The Lismore Limestone (broadly equivalent to the Islay Limestone) can be extended from Lismore SW until it is truncated by the ORS and NW until it meets the Great Glen Fault. Southeast of Lismore, there are two poorly-defined ridges running parallel with the strike of the beds on southern Lismore, the more southeasterly one being interpreted as the Appin Quartzite because it crops out on Creag Island (Hickman 1975). The stratigraphy in this area, therefore, youngs towards the NW. To the SE of the Appin Quartzite ridge one would expect to find, by extension from what is seen in Appin and Benderloch (Litherland 1980), the core of a major anticline, the Airds Hill Anticline, within the incompetent beds of the Leven Schist. Further SE of this there should be a SE-younging succession, passing upwards from the Appin into the Argyll Group. Unfortunately, none of this is visible because of the thickness of the Quaternary sediment cover, until the area offshore from the middle of Kerrera. In this area there are a series of narrow SW-tapering ridges that are interpreted as tight fold noses, plunging gently SW. This interpretation is consistent with a position in the core of the Airds Hill Anticline and a stratigraphic position low in the Appin Group. If the axis of this major fold does lie in this zone of tight minor folds, the major fold axis probably continues SW into the area of deep water and subdued relief NW of Insh Island, before disappearing under the ORS unconformity.

The SE limb of the Airds Hill Anticline in the AppinBenderloch area is cut by a major extensional fault which cuts out a variable amount of Appin and Argyll Group stratigraphy, from as low as the Leven Schist to as high as the Easdale Slates. This fault, the Ballachulish-Benderloch Slide was extended by Anderton (1988) southwestwards down the Firth of Lorn to join up with the Scarba Fault, and the whole structure is interpreted as a syn-depositional basin-bounding fault defining the edge of the Easdale Slate basin. The Insh Fault can now be identified as the central section of this fault system with the consequence that, at least from offshore Kerrera to opposite Loch Spelve, this fault may well separate the Leven Schist on the W from the Easdale Slates, overlain by ORS, to the E. Although originating as a Dalradian depositional feature, this fault must have been active during the deposition of the ORS and may have defined the local edge of the ORS basin, in the same way that the Great Glen Fault defines the local edge of the ORS on the NW side of the Firth.

\section{Discussion}

The survey data presented here have revealed the detailed geological structure and stratigraphy of the Firth of Lorn. Superimposed over the main stratigraphic and structural elements are the more recent depositional features, testament to the region's glacial and post-glacial evolution. The strong tidal flows, a characteristic of the Firth, also have influenced the seabed geomorphology. Given the diversity of geomorphological features displayed, here we discuss a few of the major features that have implications for the region's geological evolution. 


\subsection{Seabed structural controls - faulting}

Of particular note, and the feature that dominates the survey, is the $24 \mathrm{~km}$-long, $150 \mathrm{~m}$-high lineament, termed here the Insh Fault. Anderton (1988) noted this as a major structural element, as had others (Barber et al. 1979); however, the correlation of the Benderloch-Ballachulish Slide and the Scarba Fault was only assumed on the basis of onshore outcrop geology. The origins of the fault are complex and not fully understood, but appear to include phases of both Dalradian and ORS age extensional faulting, with downthrow towards the SE on both occasions. The older, Dalradian rocks on the upthrown, NW side of the fault have been preferentially eroded so that the original relief along the fault has been reversed, making it a fault-line scarp, rather than a fault-scarp. The fault line disappears under Quaternary sediments $\mathrm{N}$ of Kerrera, but its strike is correct for it to link with the Benderloch-Ballachulish Slide to the N, as suggested by Anderton (1988). To the SW, it appears to link with the Scarba Fault, but splays may also pass $\mathrm{E}$ of Lunga and $\mathrm{W}$ of Eilean Dubh Beag.

The submarine cliff has potential for being a refuge for vulnerable habitats (e.g. cold water corals, deep-water gorgonians), as well possibly having an influence on the circulation of waters within the Firth. The fault, when viewed in the wider context of the extensive faulting visible on the seabed, is part of a number of extensive faults and fault splays that represent the regional extensional tectonics since the Caledonian Orogeny. The main Great Glen Fault has only a muted seabed expression, and its location across the SE area of Mull suggests that its control on seabed morphology is limited.

\subsection{Evidence of glaciation}

Evidence for Quaternary glaciation and post-glacial environmental change is pervasive in the surveys, in particular the linear ridges, interpreted as glacial moraines. The moraines extending from Loch Don on Mull to Kerrera are especially notable in their linear extent and their excellent state of preservation. This excellent preservation is certainly not diagnostic of moraine age, but it does suggest that the moraines are lateglacial, possibly Younger Dryas, in origin. These moraines have been noted before from a short area of survey (McIntyre 2012), and were described as Younger Dryas, although their precise age remains unresolved. However, the complex of arcuate moraines interpreted as occurring between Lismore and Mull is more puzzling, exhibiting a superimposed character that suggests phases of ice advance, still-stand and retreat. This complex pattern is not noted elsewhere and is difficult to interpret, especially in the context of the large, simple linear moraines between Mull and Kerrera. One possible scenario is localised ice becoming topographically pinned against the shallow water areas, against the Mull side, with further ice transported down the Firth of Lorn to the SW, leading to competing glacial sources, one local from Mull and one more persistent from Loch Linnhe. The lack of obvious glacial features to the SW of the survey, in the outer Firth, is an indication of the influence of the strong tidal streams, combined with the lack of sediment cover available to preserve any features. However, some streamlined bedrock is evident and, given that the interpreted onset zone is further out on the shelf (Howe et al. 2012), this streamlining is perhaps not surprising.

\subsection{Submarine dune development}

The strong tidal flows in evidence towards the south of the survey, driven by the flow of water through the Gulf of Corryvreckan, and the Grey Dogs Race (or Little Corryvreckan), provide a unique opportunity to examine both the detailed seabed stratigraphy around Jura, Scarba and the Sound of Luing. They also reveal the effect of strong turbulent flows on sedi- ment mobility. A similar study, also based on bathymetric surveys and seabed sampling, in the Bay of Fundy (Shaw et al. 2012; Li et al. 2013), enables comparisons with the features around Corryvrecken. The Bay of Fundy has the largest tides in the world (16.3 m; O'Reilly et al. 2005) and flow velocities of up to $5 \mathrm{~m} \mathrm{~s}^{-1}$ (Shaw et al. 2012). The Gulf of Corryvreckan only has tidal heights of approximately $4 \mathrm{~m}$, but has similarly high velocities as a result of the constriction of flow between Jura and Scarba. Submarine dunes and bedrock swept free of sediment are noted from both areas; in particular, the development of banner banks, pairs of banks either side of a bedrock high or headland (Dyer \& Huntley 1999). The submarine dunes formed to the E and $\mathrm{W}$ of the Gulf of Corryvreckan are interpreted as banner banks. The main submarine dune field, developed in deeper water to the west of Corryvrecken, is comparable to the Minas Passage dunes, with the exception that these features occur in much deeper water. The Minas Passage study demonstrates the complexity of features that can develop under strong tidal flows, limited sediment mobility and with the interplay of bathymetry from exposed (exhumed) bedrock surfaces. The Minas Passage displays gravel mega-ripples, banner banks, dunes and sand waves resulting from the flow. The Minas Passage situation is interpreted as being similar to that of the Corryvreckan, although further study (e.g., sediment modelling combined with detailed sedimentary mapping and hydrodynamic observations) is required to fully understand the development and, to some extent, age of these features. The evolution of the Minas Passage system is interpreted to have its origins in Holocene tidal amplification and sea level rise around $3.4 \mathrm{ky}$ BP. Whilst the Minas Passage features are linked to the wider evolution of the Bay of Fundy, and the change in physical conditions of the estuary, the Firth of Lorn, essentially being a deep-water region of complex bathymetry, might not have such a strong sea level control, although it is certainly probable that the development of the dunes is linked to changing post-glacial tidal conditions.

The INIS Hydro survey has revealed the complex bathymetry of the Firth of Lorn, a bathymetry influenced by the bedrock structure and subsequent glacial and post-glacial history. As further surveys become available, notably the Civil Hydrography Program (CHP) surveys across the Hebrides Shelf, this geologically complex and diverse region will become better understood. This relatively modest region of the UKCS has shown how powerful comprehensive bathymetric surveys can be in providing new insights into the tectonic, hydrodynamic and environmental evolution of this previously poorly understood region.

\section{Conclusions}

A recent $553 \mathrm{~km}^{2}$ high-resolution multibeam echo-sounder bathymetric survey of the Firth of Lorn, western Scotland, has revealed the structure and seabed geology of the region. The seabed is predominantly characterised by bedrock and a series of narrow, stratigraphically-constrained depositional basins within the Proterozoic and Palaeozoic-age bedrock.

The basement throughout the area is composed of Dalradianage metasediments unconformably overlain by Silurian-age Old Red Sandstone and lavas. The resistant submarine rock platforms that form the shallow water areas $(<50 \mathrm{~m})$ are composed of a variety of rock types, including Dalradian quartzites, tillites and slates, as well as ORS sediments and volcanics.

The region is dominated by a $24 \mathrm{~km}$-long vertical cliff that is interpreted as the seabed expression of a fault, here termed the Insh Fault. The origins of the fault are not well understood, but appear to be a combination of Dalradian-age faulting and erosion of the softer metasediments of the central 
basin. This fault can be traced NE, where it coincides with the Scarba Fault in the S of the study area, and $\mathrm{N}$, where it has been previously been referred to as the BenderlochBallachulish Slide (Anderton 1988).

Evidence for past glaciation is extensive throughout the region, with rock streamlines, megaflutes, drumlins and preserved seabed moraines common. Typically, the regions of the inner Firth of Lorn contain numerous moraines, whilst the outer Firth of Lorn is characterised by subglacial erosion. It is assumed that all these features were produced during the late glacial of the Devensian $(<20 \mathrm{ky})$.

The surveys include the extreme tidal flows of the Gulf of Corryvreckan and Grey Dog's Race. Here, submarine dune developments are revealed, to the $\mathrm{E}$ and $\mathrm{W}$ of the gulf. The dunes are elongate in shape, up to $1.7 \mathrm{~km}$ long, display a series of crests, and are assumed to have formed as tidal flow velocities rapidly decrease away from the channels.

These initial geomorphological and geological interpretations of the survey data reveal the Firth of Lorn to be a geologically diverse region and show how new, high-resolution multibeam data can provide additional information on seafloor outcrop geology and geological history. Future work will focus on examining the benthic habitats and geological setting of the Insh Fault and the dynamic setting of the submarine dune development in the Gulf of Corryvreckan. Additional surveys using an autonomous underwater vehicle (AUV) with a remotely operated vehicle (ROV) would provide detailed seabed imagery and photography.

\section{Acknowledgements}

The INIS Hydro survey is part-financed by the European Union's INTERREG Iva Cross-border programme managed by the Special EU Projects body. The authors would like to thank project partners: the Maritime and Coastguard Agency; the Geological Survey of Ireland; the Marine Institute, Galway; the Northern Lighthouse Board; the Agri-Food and Biosciences Institute; and the UK Hydrographic Office. Reson Offshore Ltd and the British Geological Survey are thanked for technical support. RA is funded by the EU Marie Curie International Training Network GLANAM (Glaciated North Atlantic Margins). The research leading to these results has received funding from the People Programme (Marie Curie Actions) of the European Union's Seventh Framework Programme FP7/2007-2013 under REA grant agreement no. 317217.

\section{References}

Anderton, R. 1985. Sedimentation and tectonics in the Scottish Dalradian. Scottish Journal of Geology 21(4), 407-36.

Anderton, R. 1988. Dalradian slides and basin development: a radical interpretation of stratigraphy and structure in the SW and Central Highlands of Scotland. Journal of the Geological Society, London 145, 669-78.

Arnaud, E. \& Fairchild, I. J. 2011. The Port Askaig Formation, Dalradian Supergroup, Scotland. In Arnaud, E., Halverson, G. P. \& Shields-Zhou, G. (eds) The Geological Record of Neoproterozoic glaciations. Geological Society, London, Memoir 36, 635-42.

Bradwell, T., Fabel, D., Stoker, M., Mathers, H., McHargue, L. \& Howe, J., 2008, Ice caps existed throughout the Late glacial interstadial in northern Scotland, Journal of Quaternary Science 23, 401-07.

Barber, P. L., Dobson, M. R. \& Whittington, R. J. 1979. The geology of the Firth of Lorne, as determined by seismic and dive sampling methods. Scottish Journal of Geology 15, 217-30.

Binns, P. E., McQuillin, R. \& Kenolty, N. 1974. The Geology of the Sea of the Hebrides. Institute of Geological Sciences Report No. 73/14. $43 \mathrm{pp}$.
British Geological Survey. 1987. Argyll sheet $56^{\circ} \mathrm{N}-06^{\circ} \mathrm{W}$, Solid Geology 1:250,000 Sheet. London: HMSO for the British Geological Survey.

Brown, C. J \& Blondel, P. 2009. Developments in the application of multibeam sonar backscatter for seafloor habitat mapping. Applied Acoustics 70, 1242-47.

Cazenave, P. 2012. Past and Present Sediment Transport of the Northwest European Continental Shelf. Unpublished PhD Thesis, University of Southampton.

Crump, P. 2013. Report of Survey, Hydrographic Instruction 1354: Inner approaches to the Firth of Lorn. UK Hydrographic Office.

Davies, H. C., Dobson, M. R. \& Whittington, R. J. 1984. A revised stratigraphy for Quaternary deposits on the inner continental

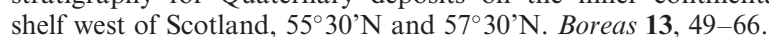

Dobson, M. R. \& Evans, D. 1974. Geological structure of the Malin Sea. Journal of the Geological Society, London 130, 475-78.

Dyer, K. R \& Huntley, D. A. 1999. The origin, classification and modelling of sand banks and ridges. Continental Shelf Research 19, 1285-330.

Eden, R. A., Ardus, D. A., Binns, P. E., McQuillin, R. \& Wilson, J. B. 1971. Geological investigations with a manned submersible off the west coast of Scotland 1969-1970. Institute of Geological Sciences Report No. 71/16. 49 pp.

Fader, G. B. J. 1991. Gas-related sedimentary features from the eastern Canadian continental shelf. Continental Shelf Research 11, 112353.

Fader, G. B. J. 1997. The effects of shallow gas on seismic reflection profiles. In Davies, T. A., Bell, T., Cooper, A. K., Josenhams, H., Polyak, L., Solheim, A., Stoker, M. S. \& Stravers, J. A. (eds) Glaciated Continental Margins: An atlas of acoustic images. London: Chapman and Hall. 315 pp.

Fyfe, J. A., Long, D. \& Evans, D. 1993. The geology of the MalinHebrides sea area. London: HMSO for the British Geological Survey.

Hickman, A. H. 1975. The stratigraphy of late Precambrian metasediments between Glen Roy and Lismore. Scottish Journal of Geology 11, 117-42.

Holgate, N. 1969. Palaeozoic and Tertiary transcurrent movements on the Great Glen Fault. Scottish Journal of Geology 5, 97-139.

Howe, J. A., Dove, D., Bradwell, T. \& Gaferia, J. 2012. Submarine geology and glacial history. Marine Geology 315-318, 64-76.

Judd, A. \& Hovland, M. 2007. Seabed fluid flow; the impact on geology, biology and the marine environment. Cambridge: Cambridge University Press. $475 \mathrm{pp}$.

Li, M. Z., Shaw, J., Todd, B., Kostylev, V. E. \& Wu, Y. 2013. Sediment transport and development of banner banks and sand waves in an extreme tidal system: Upper Bay of Fund, Canada. Continental Shelf Research 83, 86-107.

Litherland, M. 1980. The stratigraphy of Dalradian rocks around Loch Creran, Argyll. Scottish Journal of Geology 16, 105-23.

McIntyre, K. L. 2012. Offshore records of late glacial ice extent and deglaciation, Loch Linnhe, western Scotland. Unpublished $\mathrm{PhD}$ Thesis, University of Aberdeen.

McIntyre, K. L \& Howe, J. A. 2010. Scottish west coast fjords since the last glaciation: a review. In Howe, J. A., Austin, W. E. N., Forwick, M \& Paetzel, M. (eds) Fjords, systems and archives. Geological Society, London, Special Publication 344, 305-29. London, Bath: The Geological Society.

Ó Cofaigh, C., Dunlop, P. \& Benetti, S. 2012. Marine geophysical evidence for Late Pleistocene ice sheet extent and recession off northwest Ireland. Quaternary Science Reviews 44, 147-59.

O'Reilly, C. T., Solvason, R. \& Solomon, C. 2005. Where are the World's Largest Tides? In Ryan, J. (ed.) Bedford Institute of Oceanography Annual Report 2004, 44-46.

Shaw, J., Todd, B. J., Li, M. Z. \& Wu, Y. 2012. Anatomy of the tidal scour system at Minas Passage, Bay of Fundy, Canada. Marine Geology 323-325, 123-34.

Stephenson, D. \& Gould, D. 1995. British regional geology: the Grampian Highlands (4th edition). London: HMSO for the British Geological Survey.

Stoker, M. S., Bradwell, T., Wilson, C., Harper, C., Smith, D. \& Brett, C. 2006. Pristine fjord land system revealed on the seabed in the Summer Isles region, NW Scotland. Scottish Journal of Geology 42, 89-99.

Trewin, N. H. \& Thirlwall, M. F. 2002. The Old Red Sandstone. In Trewin, N. H. (ed.) The Geology of Scotland, 4th Edition. London, Bath: The Geological Society. viii $+576 \mathrm{pp}$. 